\title{
Revisiting a Moral Panic: Ascetic Protestantism, Attitudes to Alcohol and the Implementation of the Licensing Act 2003
}

\author{
by Henry Yeomans \\ University of Plymouth \\ Sociological Research Online, Volume 14, Issue 2, \\ $<$ http://umw.socresonline.org.uk/14/2/6.htm/> \\ doi:10.5153/sro. 1908
}

Received: 9 Mar 2009 Accepted: 5 May 2009 Published: 30 Mar 2009

\begin{abstract}
This paper examines the popular reaction to the implementation of licensing reforms in England and Wales in 2005. It characterises these events as an episode of moral panic and seeks an ideological explanation for this alarmist response. Utilising historical perspectives, the paper draws particular attention to the formative importance of the Nineteenth Century in terms of constructing contemporary public attitudes towards alcohol. This paper draws on existing sociology and social history to highlight an international and chronological pattern which suggests a connection between Victorian temperance movements and ascetic brands of Protestantism. Through a consideration of Max Weber, E.P. Thompson and a variety of primary sources, an interpretive explanation for this pattern is provided. Legal evidence, showing the growth of alcohol regulation and the partial enforcement of temperance codes of behaviour, is then used to illustrate the survival and secularisation of temperance views from the Nineteenth Century onwards. An interpretive analysis of public discourse surrounding licensing reform in 2005 provides empirical support for this argument. Attitudes to alcohol exhibited during this episode were found to bear qualitative similarities to Calvinist-inspired temperance beliefs. The paper argues that ascetic Protestant attitudes to alcohol have achieved a wide currency and now occupy a hegemonic position within secular British society. The public reaction to the implementation of the Licensing Act 2003 is thus reinterpreted as a moral panic largely constructed by ascetic Protestant beliefs.
\end{abstract}

\section{Keywords: Alcohol, Attitudes, Morality, Calvinism, Ascetic Protestantism, Licensing Act 2003, Temperance}

\section{Introduction}

1.1 The Licensing Act 2003 came into effect in November 2005. Its stated aims were to reduce crime and disorder, reduce alcohol misuse, encourage tourism and assist self-sufficient rural communities (Explanatory Notes, 2003). The most eye-catching measure contained within this legislation was the liberalisation of opening hours allowing pubs, clubs and shops to apply for licences to sell alcohol later into the night and potentially for twenty-four hours per day. In practice twenty-four hour licences were granted to only a handful of premises (mainly supermarkets), with the majority of pubs and clubs applying to stay open for an extra one or two hours (Travis et al, 2005) ${ }^{[1]}$. Despite this negligible effect on the alcohol trade, there was widespread public anxiety surrounding the implementation of this law.

1.2 Politicians, magistrates, police and journalists were amongst those vocal in their dismay at the legal reform - the main criticism being that this Act would worsen problems of crime and disorder already seen by many as 'out of control'. The Daily Telegraph reported that the British Transport Police had serious concerns over a likely increase in violence (Alleyne, 2005) and The Observer highlighted how many magistrates as well as senior police officers believed the new laws would increase rape and sexual assault (Townsend \& Hinscliff, 2005). Shadow Secretary for Culture, Media and Sport, Theresa May, said that 'longer drinking hours will mean more crime and disorder' (Travis et al, 2005); Liberal Democrat MP Mark Oaten described the plans as 'madness' (Plant \&Plant, 2006: 100); and Charles Harris QC said the Licensing Act was 'close to lunacy' (Plant \& Plant, 2006: 109). Much of the backlash centred on the government's aim to create a more open, relaxed and continental drinking culture - a goal seen by many as preposterous. The actor Tony Booth publicly declared that the British drink in 'a more primitive, frightening, Anglo-Saxon way' than our European neighbours (Plant \& Plant, 2006: 108) - a point corroborated by Charles Harris QC who stated that after drinking British people become 'pugnacious and bellicose' and 
'fight at the slightest provocation' (BBC, 2005). The tone of much public discourse surrounding was severe and near-hysterical.

1.3 The purpose of this paper is to seek an explanation for this moral panic. Why did a legal reform with rather limited practical implications provoke such a response? How can the views of public figures who labelled the Act 'madness' be explained? Recognising that the events of 2005 were by no means the first alcohol-related social panic in Britain, this paper will combine contemporary discourse analysis with a longer-term, historical perspective. The first section, 'Moral Panics and Historical Processes', discusses moral panic theory and its applicability to this paper. 'Alcohol Panics in Historical Perspective' then explores international and historical patterning of temperance attitudes before 'Calvinism and Temperance Beliefs' presents an interpretive explanation of this pattern. In 'Achieving Hegemony', legal sources are used to trace the development of attitudes towards alcohol from the demise of the temperance movement onwards. 'Reinterpreting the Moral Panic of 2005' employs popular discourse to reconstruct the moral panic of 2005 and, drawing on the previous sections, seeks discursive evidence of the persistence of temperance attitudes. The article thus takes the form of a historical discourse analysis, continually informed by, and framed within, sociological theory. The explanation for the moral panic of 2005 that is advanced will therefore be historical and interpretive.

\section{Moral Panics and Historical Processes}

2.1 In order to understand the events surrounding the implementation of licensing reforms in 2005 it is necessary to give some discussion of what a moral panic constitutes. Moral panics can be described as official reactions to certain social phenomenon that are entirely disproportionate to the actual level of threat posed (Jenkins, 2009: 35). In Stanley Cohen's famous definition, a condition, person or group of people comes to be viewed as a threat to societal values and interests with the result that the 'moral barricades are manned by editors, bishops, politicians and other right thinking people' (1972: 9). This noisy reaction by establishment figures draws public attention to the issue and wider condemnation often ensues. The end result of this panic, according to Cohen, is that 'ways of coping are evolved or (more often) resorted to' and consequently 'the condition disappears, submerges or deteriorates and becomes more visible (1972: 9).

2.2 This traditional conception of moral panics has been the subject of much criticism and debate. Of particular relevance to this paper is Cohen's inference that episodes of moral panic are exceptional rather than routine - societies are only subject to moral panics 'every now and then' (1972: 9). Underlying Cohen's definition is a presupposition that there is some kind of natural social equilibrium that is occasionally imbalanced by perceptions of novel or emergent behaviour. This position has been contested, for example Rowbotham and Stevenson claimed that in Victorian and contemporary periods episodes of moral panic are frequent and, in media representations and popular understandings, often muddled together. Hence, Rowbotham and Stevenson seek a 'less-disjointed approach' to the issues, preferring the term 'social panic' which reflects the current state of endemic rather than exceptional cases of alarmist public discourse (2003: 8). In reference to attitudes to alcohol, this less-disjointed approach seems more suitable as, since the temperance movement in the Nineteenth Century, alcohol has proved a recurrent theme in public discourse. There was virtual hysteria about the effects of drink on national efficiency during World War One, experiments with nationalisation of the alcohol trade in the 1920s, the growth of interest in issues of health and addiction from the 1950 s onwards, ${ }^{[2]}$ and the resurgence of concern for the effects of alcohol consumption upon law and order from the 1980 s to the present. The idea that public anxiety about alcohol is temporary is thus questionable.

2.3 Expanding on this critique, Critcher (2009) attempts to locate episodes of moral panic within longer term processes of moral regulation. Moral regulation was defined by Corrigan and Sayer as 'a project of normalizing, rendering natural, taken for granted, in a word "obvious", what are in fact ontological and epistemological premises of a particular and historical form of social order' (Corrigan 1985: 4). In their analysis, moral regulation is conceived of as an activity predominantly undertaken by the state in order to justify and perpetuate its own existence and social interventions. Moral regulation theory has since been altered slightly, notably by Hunt whose research includes the study of non-state actors within moral regulation projects and also emphasises their construction of ethical subjectivities (1999). Theorists such as Ruonavaara (1997) and Critcher (2009) agree with Hunt to the extent that they share a concentration on the creation of social identities as well as ideas of who we are and how we should behave. This discursive focus resonates with the issue of alcohol; in the Nineteenth Century the temperance movement promoted the behavioural standard of abstinence as an essential condition of the responsible, hard-working and moral citizen. The temperance movement's construction of this ethical subjectivity demonstrates an attempt to create new behavioural codes, to ethically reform people's ways of living and, in short, to morally regulate the lives of the population. The long term discursive focus of moral regulation appears well-suited to the study of attitudes to alcohol. 
2.4 Although recognising the strengths of moral regulation, Critcher (2009) argues that the concept of a moral panic must be retained. Normative concerns for public behaviour and social order may be encapsulated within long term discursive processes, but they are certainly not even throughout history. For example, the official reaction to issues of labour efficiency during World War One led Lloyd George to declare that alcohol was a bigger threat to Britain than the Germans or Austrians (New York Times, 1915). This episode appears as a peak in Twentieth Century anxiety about alcohol and it was not until after the Second World War that alcohol once again became seen as an especially acute social problem. Critcher argues that, because moral regulation is a routine feature of modern society, a separate conceptual category is needed to describe these heightened periods of concern (2009: 30-32). Critcher thus seeks to overcome some of the inherent weaknesses of moral panic theory by defining episode of moral panic as extreme and temporary developments in moral regulation processes.

2.5 Critcher's synthesis also addresses another prominent criticism of moral panic theory. The work of Cohen and others rests on a comparison of the perceived to the actual; a disproportionate reaction being irrational and indicative of panic. This position has been widely criticised including by Hunt, whose social constructivist view of knowledge makes him suspicious of any comparison of real and imagined or true and false (Purvis and Hunt, 1993: 497). Hunt's own research thus seeks to describe and understand certain forms of moral politics rather than dismiss them as deformations of reality. Critcher rejects this approach and argues that social sciences must have a political purpose; if research and learning is not to be used to discern reality from representation then what exactly is the point? (Critcher, 2009: 32) Casting the social scientist in the role of expert is, perhaps, a bold move by Critcher, but the idea that empirical work may produce conclusions with a greater claim to validity than lay opinions is not especially radical. Although simplistic positivism has been discredited, research approaches such as realism defend the idea that there is a social reality independent of human perception which research must seek to understand or uncover. ${ }^{[3]}$ This paper contends that whilst social science continues to harbour credible epistemologies that acknowledge the existence of 'the real', heuristic devices and explanatory techniques such as moral panic theory can reasonably retain the practice of separating the actual from the imagined and the rational from the irrational.

2.6 Following Critcher's theoretical developments, this paper views the reaction to the implementation of licensing reforms in 2005 as a moral panic for two reasons. Firstly, it was an intensified period of concern about alcohol use in Britain within longer term processes that have constructed alcohol as a social problem. Secondly, the reaction appears irrational and disproportionate to the level of threat actually posed. This is partly because of the diminutive number and length of licence extensions granted and also due to the negligible effect on crime and disorder. The Department of Culture, Media and Sport's evaluation of the Licensing Act 2003 found no uniform detrimental effects (DCMS, 2008) and Home Office statistics show that crime levels continued to fall from 2005 to 2008 (Kershaw et al, 2008). Although it is easier to appreciate in retrospect, the mayhem widely predicted clearly did not materialise. In the absence of any rational support for the public outrage, this paper thus seeks a moral and ideological explanation for the events of 2005.

\section{Alcohol Panics in Historical Perspective}

3.1 Acknowledging that the events of 2005 were not entirely exceptional, it is useful to consider Britain's long history of social anxiety relating to alcohol. Probably the first major example of alcohol-related anxiety was the 'gin panic' which gripped London in the first half of the Eighteenth Century. Perhaps unsettled by structural changes such as rapid urbanisation, middle class elites complained about a breakdown in social order (Borsay, 2003: 4-5). Gin and other alcoholic spirits were charged with making men idle, turning women into bad mothers and a litany of other social ills. The gin panics did not target alcohol per se as a social problem, focusing instead on the negative consequences of excessive consumption of certain types of drink. In the Nineteenth Century, however, British conceptions of alcohol were drastically altered. The 1830s saw the beginnings of the temperance movement as campaigning groups sprang up across the country. Temperance societies, such as the UK Alliance and the British and Foreign Temperance Society, believed alcohol to be an evil substance that must be avoided through either full legal prohibition or a personal pledge of abstinence. Temperance groups were very popular and, by 1889 , the Band of Hope society alone claimed around two million members (Bailey et al, 2007: 150). Although temperance societies were in decline by 1900, earlier discussion of Twentieth Century concerns for efficiency, health and crime showed that alcohol has nonetheless remained on the political agenda. This chronology of persistent alcohol panics since the Nineteenth Century suggests that the temperance movement had a decisive impact on the way alcohol is viewed in Britain. As Harrison states, 'the temperance movement forced society to recognise drunkenness as a serious social evil' (1971: 28).

3.2 The advent of the temperance movement thus appears as something of a turning point in British history; but it is not a turning point unique to Britain. Levine identifies eight other temperance nations who have shared similar historical experiences; these are the USA, Canada, Australia, New Zealand, Sweden, 
Iceland, Norway and Finland (Levine, 1993). All of these countries experienced strong teetotal or prohibitionist social movements in the Nineteenth Century and continue to possess serious misgivings about alcohol consumption that are reflected in strict legal regulation of the alcohol trade and regular moral panics. ${ }^{[4]}$ In order to explain Britain's 'alcohol problem', it would be useful to examine what Britain has in common with these other temperance countries. Two common explanations propose that either industrialisation or high levels of consumption of spirits produce temperance movements (Levine, 1993). Engels argued that industrial capitalism imposes physical and mental strains on the individual to which no relief is possible other than through 'maddest excess in the only two enjoyments at their command' - sex and alcohol (Engels, 1993: 109). But if Engels is correct, why are other industrialised countries such as France or Germany non-temperance? Similarly, the contention that drinking spirits produces more disorder and ultimately an anti-alcohol reaction is an argument weakened by the non-occurrence of temperance in Poland or the Czech Republic who both consume larger quantities of alcohol per capita in the form of distilled spirits than any of the nine temperance cultures (WHO, 2004: 13). Current explanations of temperance sentiments do not therefore hold up to comparative scrutiny.

3.3 Clearly a new explanation of why certain countries become particularly concerned about alcohol is needed. Another factor Levine draws attention to is religion and, in particular, the strong historical presence of ascetic Protestantism in all nine temperance nations. This brand of Protestantism encompasses Calvinist-inspired denominations, such as Methodism, Baptism and Presbyterianism, whose international strength corresponds well with temperance sentiments (Levine , 1993). In regards to British regions it is also evident that temperance groups were strongest in areas where Non-conformism was rife, such as the South-West, the North and Scotland, yet weak in the South East where the more Lutheran-influenced Church of England was dominant (Warner, 2003: x,Shiman, 1988: 9). But this pattern is more than mere geographic association: Gusfield describes how the American temperance movement drew particular support from Calvinist congregations (Gusfield, 1962: 105-107), Eriksen documents how the Swedish temperance movement was instigated by ascetic Protestant missionaries (Eriksen, 1989) and Harrison documents the overwhelmingly Calvinist constitution of the early teetotal movement in Britain (Harrison, 1971: 179). As ascetic Protestants were active in the early temperance movement, it becomes feasible that the connection with temperance movements may have some causal substance to it.

3.4 Although the association of ascetic Protestantism and the British temperance movement is welldocumented, the reasons behind this association are not well explored. The next section will offer an ideological explanation of the relationship between these two historical phenomena.

\section{Calvinism and Temperance Beliefs}

4.1 It was famously argued by Durkheim that Protestantism is more individualistic than Catholicism and substitutes personal self-control for confessionary rituals (Durkheim, 1970: 374-375). According to Weber, this belief in self-control is further inflated by Calvinist strands of Protestantism. The Protestant Ethic proposes that the Calvinist belief in predestination shifts people's focus away from achieving a state of grace, which is the abiding concern of Lutheranism or Catholicism, and towards proving your own state of grace (Weber, 1965: 98-103). Weber argues that proving one's own election is achievable through 'rational worldly activity' - working hard, saving money and controlling emotional or physical impulses become behavioural imperatives (Weber,1965: 126-127). Calvinism thus intensifies the Protestant idea of self-control and places a powerful spiritual currency upon hard labour, financial thrift and other rational worldly activities. If alcohol costs money, disinhibits behaviour, inclines its imbibers towards spontaneity, and reduces capacity for work (both when consuming and often the next morning), it is apparent why such a thing would be moral anathema to Calvinists. It also becomes clear why more Lutheran countries, such as Germany or Denmark, did not witness large-scale temperance movements - their underlying religious ethics would not ably support this intensified reaction.

4.2 Additionally, Lutheran strains of Protestantism did not view pleasure and recreation with the suspicion which came to characterise Calvinist views of the subject. Calvinism conceives of the earthly and the divine as entirely separate spheres (Weber, 1965: 102-103) and, whilst God is perfect, human beings are essentially depraved, sinful creatures. Thompson quotes the Nineteenth Century Methodist preacher Jabez Bunting's claim that 'the dust of self-abasement is our place before God' (Thompson, 1980: 400) and so consequently guilt, shame and self-repulsion are the only emotions suitable to mankind. The classic puritanical view that pleasure is immoral arises from these ideas as recreation comes to be seen as a waste of time which could be used for rational labour, but also an act of reveling in the vulgarity of humanity and thus an affront to God. As drinking was, to a fair extent, a recreational activity, it contravened acceptable Calvinist codes of behaviour. It starts to become clear why, to the Calvinist mindset, total avoidance of alcohol was the only reasonable course of action. The pejorative definition of pleasure renders any enjoyment taken from drinking as intrinsically immoral and it is recognised that 'the only true mode of killing drunkenness and the equally mischievous habits of "moderate" tippling is the adoption of Teetotal 
4.3 Temperance activists often explained their beliefs with reference to a glut of social ills attributed to alcohol. A letter published in The Times in 1830 claimed that 'the worst cases of murder, street robbery, housebreaking, seduction, and suicide, may all be traced to this horrid source' (The Times, 1830). This is not remarkable in itself; it is generally accepted in most modern societies that alcohol contributes to certain social problems such as crime and ill-health. What distinguishes temperance beliefs is, firstly, the inflated scale of alcohol's culpability for these social problems, embodied in temperance campaigner F.W Farrar's approving quotation of Mr Justice Denman's remark that 'drunkenness is the parent of all crime' (Farrar, 1893: 790); and, secondly and more importantly, to temperance believers the first sip of beer was regarded as the beginning of a slippery slope. Temperance activist W. Hunt used the metaphor of a whirlpool to describe how even moderate drinkers soon find that 'their giddy heads quickly sink in the deep waters of intemperance - perhaps to rise no more' (Hunt, 1841: 14). The negative potential consequences of alcohol use came to be viewed as the inevitable result of even modest consumption. Individuals lacking in selfdiscipline, refusing to deny themselves pleasure and indulging in drink were thus initiating their own descent into an uncontrollable, downward spiral of earthly sin and misery.

4.4 The pejorative definition of pleasure, in addition to the intensified ideas of rationality and self-control, were the basic ideological tenets which inclined ascetic Protestants against the use of alcohol. Driven by these anxieties about order and control, temperance campaigners were able to construct a causal inevitability which depicted any consumption of alcohol as physically and morally dangerous. If pleasure was theologically suspect and recreational drinking sure to be disastrous, alcohol came to be constructed as a negative moral absolute. In 1895, the National Temperance Congress described public houses as 'insidious temptations' (The Times, 1895) and in 1901 John Burns described the concentration of 'forces of evil' within London's liquor shops (Kneale, 2001: 54). It is not implausible that faced with such a preponderance of evil within society, temperance followers may have felt overwhelmed. But for Calvinists, there was a strong impetus towards active public campaigning against activities perceived as immoral. Surrounded on all sides by sin and moral degradation, Calvinists felt obliged to take action - as Sir Wilfrid Lawson stated 'we live in a world full of sin, of wrong, and of injustice, and if we are not to struggle, the sooner we are out of this world the better' (Harrison, 1971: 377). Lacking the necessary valuation of worldly labours or vilification of pleasure, Catholic and Lutheran-dominated countries could not produce temperance movements - only the Anglo-Saxon and Nordic countries identified by Levine had the requisite ideological basis on which this historical phenomenon could develop and flourish.

4.5 Calvinist ideas thus provided a moral standpoint from which alcohol was viewed as evil. This new understanding instigated large-scale social movements against the use of alcohol in Britain and certain other countries in which ascetic Protestantism was strong. Despite this powerful ideological message and the movement's campaigning strength, temperance had largely died out by the turn of the Twentieth Century. The next section will investigate whether or not temperance ideas and beliefs were able to survive the demise of the social movement that spawned them.

\section{Achieving Hegemony: The Rise and Rise of Temperance Beliefs}

5.1 Harrison has argued that, over the course of the Nineteenth Century, the moral crusade of the temperance movement became increasingly secularised (1971: 189). This section will extend Harrison's argument and assess its relevance to the Twentieth and Twenty-First centuries. Unlike Harrison's work or other studies of this topic, this section will draw primarily on legal data.

5.2 It has been discussed how, in accordance with its Calvinist ideological ethos, the early temperance movement was very much the property of Nonconformist churches. But increasingly this social movement was adopted by Anglicans and by the 1870s the Church of England temperance society had taken over much of the campaigning momentum (Harrison, 1971: 29-32). While becoming more acceptable to Anglicans, temperance attitudes in this period also began to lose their ties to institutional religion altogether. Greenaway reports how toward the end of the Nineteenth Century licensing became a major party political issue (2003: 29-52). Annual parliamentary votes on the Permissive Bill, which would have given local authorities a veto on the trade of alcohol in their area, reveal that from 1871 onwards the Liberal Party was more inclined toward temperance than the Conservatives (Harrison, 1971: 270). Many persons involved in the emerging Labour Party, such as Keir Hardie or Sidney and Beatrice Webb, promoted temperance as a means to working-class self-betterment (Harrison, 1971: 395-396). The temperance agenda thus became increasingly identifiable within parliamentary parties and factions - a point illustrative of its presence in the heart of secular government. The secularisation of the moral crusade enabled temperance ideas to migrate from the religious peripheries and settle in the political mainstream.

5.3 The influence of temperance ideas over secular governance is evident in developments in legal regulation. Since the Licensing Act 1872 made being drunk and disorderly in a public place a criminal 
offence, there has been a proliferation of legal rules surrounding drunkenness and drunken behaviour. Often these rules have related to the protection of society from the perceived threats of alcohol. For example, the Road Traffic Act 1988 tightened drink driving laws in an attempt to reduce the occurrence of this dangerous behaviour, and the Licensing Act 1902 sought to protect children by creating a statutory offence of being drunk in charge of a child. Other developments have also concerned young people: the Licensing Act 2003 made it a criminal offence for under-18s to buy or attempt to buy alcohol and, while it is not currently illegal for this group to drink alcohol, the government has recently announced plans to give Anti-Social Behaviour Orders to young people caught drinking in public (BBC News, 2008). More general restrictions on public behaviour have also been greatly expanded and in the last fifteen years, many local authorities have banned drinking in certain public areas - an enterprise the Home Office has actively encouraged by producing a model bye-law (Home Office Circular, 1996). As with the demands of the temperance movement in the Nineteenth Century, recent legislative efforts illustrate a perceived need to limit general consumption of alcohol and reform public behaviour.

5.4 The development of licensing regulation also has affinities with temperance beliefs. From the Beerhouse Act 1830 to the reduction of import duty on wine in the 1860s, much of the Nineteenth Century was dominated by free trade approaches toward alcohol. Gladstone was certainly an adherent of this strategy, believing that with competitive pricing and sufficient choice of product individuals would avoid the most intoxicating and socially harmful drinks (Harrison, 1971: 248). But the Licensing Act 1872 called time on free trade alcohol policies and implemented a new, stricter regime. Sellers of all forms of alcoholic drinks were required to obtain a licence from local magistrates and under-16s not accompanied by an adult were excluded from entering pubs. Of course these measures were lenient compared to temperance demands, but the enforcement of Sunday closing of pubs in Scotland in 1853 and Wales in 1881 show clearer evidence of temperance influence. Although Britain never implemented national prohibition, in certain areas the 'local veto' proved more popular politically - providing it was supported in a referendum by the local population, the Temperance Act 1913 enabled areas of Scotland to enforce prohibition throughout the week. In England the temperance influence was less striking, but licensing legislation still resonates with a belief in the essentially problematic nature of alcohol. The Licensing Act 1964 restricted consumption by fixing the age for purchasing alcohol at 18 and the Licensing Act 1921 limited opening times to nine hours per day Monday to Saturday and 5 hours on Sundays. The demise of the free trade approach and the development of statutory restrictions on the alcohol trade across Britain are illustrative of the increasing acceptance of the need to regulate this dangerous substance. Temperance ideas appear to have permeated into secular government.

5.5 In certain respects, licensing legislation since the 1980s has been liberalising. The Licensing Act 1988 permitted pubs to stay open all day by allowing the sale of alcohol from 11AM to 11PM and the Licensing Act 2003 allowed pubs to apply for twenty-four licences. But this liberalising trend has been accompanied by an increase in licensing offences and new police powers. The Police and Criminal Justice Act 2001 increased the power of the police to confiscate alcohol if consumed in a public space, imposed a 'positive duty' on licensees not to sell alcohol to underage drinkers, and authorised police forces to carry out 'test purchasing' of alcohol by children in order to ensure the positive duty is complied with. The Licensing Act 2003 granted local authorities additional powers to suspend or revoke licences as well as increasing the ability of the police to temporarily close premises. Despite the headline-grabbing liberalisation of opening times, the overall intensification of licensing controls coupled with broader controls such as public drinking bans illustrate a firm governmental belief in the fundamentally problematic nature of alcohol consumption. The ongoing, post-Victorian project of restricting the sale and use of alcohol demonstrates a pervasive secular desire to limit alcohol consumption.

5.6 The previous section highlighted the importance of Calvinist ethics in the Victorian redefinition of alcohol; this section has shown that the Nineteenth Century temperance project of regulating alcohol and reforming behaviour was continued by secular governments until the Twenty First Century. Considering that temperance attitudes have become secular hegemonic assumptions, the next section will examine whether ascetic Protestant beliefs which were crucial in the advent of temperance have attained a similar longevity and status. This question will be investigated in reference to the moral panic of 2005.

\section{Reinterpreting the Moral Panic of 2005}

6.1 As described in the introduction, the Licensing Act 2003 was speculatively linked to a projected explosion of violence, sexual assault and general disorder. On the eve of the Act coming into effect, The Sun reported in battle-ready terms the creation of a 'field hospital' in Newcastle-upon-Tyne to handle the imminent 'casualties of 24-hour drinking' (Perrie, 2005). Of course the press may be prone to sensationalism, but it was not just the Daily Mail who believed that 'the binge is about to become an uncontrolled riot of drunkenness' (Daily Mail, 2005). David Blunkett MP described the Act as 'a leap in the dark' that risked worsening crime problems (Daily Mail, 2005) and Mark Oaten MP claimed that 'when the 
problem is running out of control in our town centres, extending drinking hours to twenty four hours a day is madness' (Plant \& Plant, 2006: 100). In light of the present discussion, these comments seem to illustrate a peculiarly Calvinist preoccupation with rationality, order and a perceived decline in both. To cast the reaction in temperance terms, drink problems are already 'out of control' and so extending opening times will mean further increasing social problems as even normally moderate and sensible drinkers soon find themselves in 'the deep waters of intemperance' (Hunt, 1841: 14). If, as temperance societies believed, alcohol consumption is a slippery slope, then the line between order and chaos can be as thin as a few extra hours of drinking time. The heightened nature of perils arising from alcohol consumption as well as a general anxiety about social order both echo ascetic Protestant attitudes.

6.2 These discursive formations are influenced by the 'availability theory' which articulates the idea that a greater availability of alcohol will lead to increased alcohol consumption and therefore inflated social problems (Plant \& Plant, 2006: 124). The reaction to licensing liberalisation reveals that the law is seen as protection against these dangers - if the law fails to restrict availability of alcohol, problems of crime and disorder will increase. The situation where the law, as a system of external social rules, is believed to be the most important guarantee of social order demonstrates a lack of faith in internal behavioural controls. Employing vocabulary which usually denotes unavoidable physical catastrophes, The Sun talked of casualty units being 'swamped' by victims of alcohol-related violence and accidents (Wooding, 2005) as well as 'the inevitable swarm of drunken youngsters' who bring disorder to the streets (Kavanagh, 2005). This grim fatalism and rather grandiose language depicts this disaster in entirely deterministic terms. The officially promoted solution to this problem is sticking to the recommended daily and weekly guidelines on units of safe alcohol consumption. This proscribed routine of self-discipline resonates with the temperance belief in abstinence and shows a typically puritan faith in self-denial as an indicator of personal worth. But as a BBC article revealed, at least one in four people were succumbing to the temptation of binge drinking and exceeding the daily limits of 2-3 units per day for women and 3-4 units for men (BBC, 2005). Both the recommended routine of limited consumption and the law's position as an external defence against the threat of chaos are indicative of Calvinist valuations of self-control and self-discipline.

6.3 This theme of weak self-control also portrays human nature in a particularly negative fashion. Again this can be related to the availability theory which Sumner and Parker argue relies on the assumption that alcohol is a dis-inhibiting drug that, when consumed, unlocks a Freudian dungeon of aggressive, violent and sexual impulses (Sumner \& Parker, 1995: 4). This position was vividly discernable in 2005: John Yates of the Association of Chief Police Officers spoke to The Observer about a likely increase in rape and sexual assault (Townsend \& Hinscliff, 2005) and David Davis MP warned of 'anarchy on the streets' (The Sun, 2004). Allowed access to alcohol therefore, humans will act on their innate urges, commit bestial acts and become, quite literally, the 'urban savages' which Charles Harris QC warns of (Britten, 2005). This belief seems reflexive of a Calvinist sense of self-repulsion as espoused by Jabez Bunting amongst others.

6.4 Extending this argument, various denigrating comments about British people or culture can be reinterpreted. Tony Booth's idea that Anglo-Saxon drinking habits are 'primitive' shows the adoption of a position of self-abasement; Charles Harris QC's views (quoted in the introduction) reveal a puritanical disgust with the recreational habits of the masses; and Frank Dobson's claim that the English 'have been binge drinkers since time immemorial' (Daily Mail, 2005) reflects a faith in the unwavering constancy of British national depravity. These degrading self-evaluations mean that the Licensing Act 2003 cannot improve Britain's drinking culture and stands only to worsen existing problems by removing legal constraints. Booth, Harris and Dobson demonstrate that a Calvinist sense of self-disgust has been transposed onto the national unit and popular discourse inflates this sentiment through regular comparisons with other, apparently more-civilised, European countries. Geethika Jayatilaka of Alcohol Concern said that 'extending licensing hours are more likely to turn our town centres into Faliraki than Florence' (BBC, 2005) and academic Victor Robinson asserted that 'we are not a Mediterranean people and have not been socialised into the respect for alcohol those cultures have' (BBC, 2005). Europe, and particularly southern Europe, is constructed as a beacon of civilisation which stand in stark contrast to British alcoholic depravity.

6.5 The belief in the essential depravity of the British has intensified concerns about self-control and social order. The idea of a 'binge drinking epidemic' (Daily Mail, 2005) suggests that, like temperance campaigner Sir Wilfrid Lawson, many people believe they are surrounded by (drink-induced) crime and debauchery - a situation which liberalisation is sure to worsen. However, the overriding tone of these worried commentaries was not necessarily despondent and many rallied for concerted action against alcohol consumption. A piece in The Sun stated simply that 'doing nothing isn't an option' (The Sun, 2005) and, writing in The Observer, liver specialist Professor Roger Williams argued for higher drinks prices, warning labels on bottles and cans, and more money for both preventative educational programmes and alcohol treatment facilities (Williams, 2005). Williams believed the situation to be extremely serious, writing of the numerous 'adverse consequences of our drinking culture' (Williams, 2005). But, as with Lawson, Williams' belief in 
the grave seriousness of the current situation becomes an impetus towards action. Williams may express his views with secular, medical language but his attitudes and understandings appear underpinned by the Nonconformist notion of the struggle.

6.6 Generally speaking, public discourse in 2005 exhibited few deviations from the temperance-inspired norm of hostility toward licensing reform. The Sun did run a story about a potential ban on drinking on public transport and state that this 'would mean an end to thousands of commuters enjoying a well-earned tipple on the train as they travelled home' (Lea, 2005). But other recognition of alcohol's enjoyable and nonharmful effects was rare. It is perhaps most telling that even the government responsible for the Licensing Act 2003 chose to defend it by saying it would reduce crime and disorder. Culture Secretary Tessa Jowell stated licensing reform 'will make towns and cities safe for all, not a free for all' (The Sun, 2005) and Home Secretary Charles Clarke spoke of creating a 'civilised kind of life as exists in continental Europe' (Daily Mail, 2005). Although the actions of government ministers were a challenge to the availability theory, they accept the fundamentally problematic nature of alcohol, the comparative depravity of the British and the urgent need to reform behaviour. Both the arguments for and against the Licensing Act 2003 were thus constructed within the heuristic frameworks of ascetic Protestantism.

6.7 The visibility of preoccupations with social order and self-control, a sense of personal or national selfrepulsion and a desire to struggle against overwhelmingly social problems all illustrate the continuing influence of ascetic Protestant ideas over secular attitudes towards alcohol. In the moral panic over licensing in 2005, temperance understandings of alcohol based around Calvinist ethics characterised and contributed to alarmed public discussion.

\section{Conclusion: The Iron Cage of Temperance}

7.1 Through an exploration of beliefs and attitudes, this paper has provided an interpretive explanation of the strong historical connection of temperance movements and ascetic Protestantism. It has extended Harrison's argument that temperance was secularised in the Nineteenth Century by utilising legal evidence to propose that the temperance project of regulating alcohol use and reforming behaviour has continued into the Twenty-First Century. Most importantly, it has sought to demonstrate the continuing influence of ascetic Protestant beliefs over this long term regulatory project through an analysis of the moral panic over licensing of 2005. Britain today is religiously heterogeneous and contemporary public discourse is, explicitly at least, largely secular. But the qualitative affinities between Calvinist beliefs and alarmed views expressed in 2005 demonstrate that ascetic Protestant values and understandings continue to characterise public attitudes to alcohol. The religions that created these ideologies may have decreased in influence and the social movement which promoted their normative conception of alcohol has died out. As with Weber's 'iron cage' of rationality however (Weber, 1965: 181), Calvinist-inspired temperance attitudes continue to structure thoughts, perceptions and, hence, secular views of drinking.

7.2 The availability theory may have been contested by the government in 2005 but the Calvinist morality which underlies this theory was not contested. The idea that alcohol is a social problem and the belief that this problem has reached crisis proportions in Britain are now "common sense", hegemonic assumptions. Public discourse on alcohol since 2005 seems consistent with this point. Newspapers continue to highlight the perils of booze through references to booze-fuelled 'no-go areas' (Roberts, 2008) or 'war zones' (Pascoe-Watson, 2008). In 2008, Justice Secretary Jack Straw spoke of the need to create a 'moral imperative' for young people to avoid alcohol (BBC, 2008) - effectively a behavioural routine of denial and self-control to be learned by the next generation. In 2009, Sir Liam Donaldson sparked a fierce debate by stating that 'England has a drink problem' and calling for an increase in the price of drinks to alleviate this (BBC, 2009). These recent debates must also be located within historical processes that saw the construction of alcohol as a moral problem in the Nineteenth Century and the progressive development of restrictions on alcohol from the Victorian period onwards. Following Critcher's theory, the events of 2005 thus appear as a high point of anxiety about alcohol within a long term project of moral regulation. Following the arguments presented here, this anxiety appears, in no small part, based upon and characterised by the moral and ideological premises of ascetic brands of Protestantism.

\section{Notes}

1 This article reported that only $40 \%$ of premises were granted extended licences, and of the 184,000 licensed premises in England and Wales only about 700 were granted twenty-four hour opening.

2 See Dorn (1983: 76-99).

${ }^{3}$ For an example of realism see: Bhaskar (1978) A Realist Theory of Science. 
${ }^{4}$ To elaborate, recent liberalising reforms of licensing in New Zealand and Sweden have also produced social anxieties and proceeded under intense evaluative scrutiny (Huckle et al, 2006; Norstrom and Skog, 2005). The USA and Finland were among a handful of countries to have taken alcohol seriously enough to attempt full legislative prohibition.

\section{References}

ALLEYNE, R. (2005) 'New drinks law "delays disorder for an hour”', The Daily Telegraph, 19 November 2005.

BAILEY, A.R., HARVEY, D.C., and BRACE, C. (2007) 'Disciplining Youthful Methodist Bodies in Nineteenth Century Cornwall', Annals of the Association of American Geographers , Vol. 97, pp. 142-157.

BBC NEWS (2005) 'Violence fear over new drink laws', BBC News, 10 August 2005, <http://news.bbc.co.uk/1/hi/uk/4134772.stm> .

BBC NEWS (2005) '24-hour pub opening "a disaster"', BBC News, 18 October 2005, <http://bbc.co.uk/go/pr/fr/-/hi/northern_ireland/4354462.stm> .

BBC NEWS (2005) 'One in four are binge drinkers', BBC News, 27 October 2005, <http://news.bbc.co.uk/1/hi/health/4381120.stm>.

BBC NEWS (2008) 'Drink campaign to target parents', BBC News, 1 June 2008, <http://news.bbc.co.uk/1/hi/uk/7429701.stm>.

BBC NEWS (2009) 'Brown lukewarm on alcohol pricing', BBC News, 16 March 2009, $<$ http://news.bbc.co.uk/1/hi/health/7945357.stm> .

BHASKAR, Roy (1978) A Realist Theory of Science . Hemel Hempstead: Harvester.

BORSAY, Peter (2007) 'Binge drinking and moral panics: historic parallels?', History and Policy, <http://www.historyandpolicy.org/papers/policy-paper-62.html>.

BRITTEN, Nick (2005) 'Judge says 24-hour drinking will create "urban savages"', The Daily Telegraph, 11 January 2005.

COHEN, Stanley (1972) Folk Devils and Moral Panics . London: MacGibbon and Kee.

CORRIGAN, Philip, and SAYER, Derek (1985) The Great Arch: English State Formation as Cultural Revolution. Oxford: Basil Blackwell.

CRITCHER, CHAS (2009) 'Widening the Focus: Moral Panics as Moral Regulation', British Journal of Criminology, Vol. 49, pp. 17-34.

DAILY MAIL (2005) 'A drink sodden law that no one wants', Daily Mail, 12 January 2005, <http://www.dailymail.co.uk/news/article-333807/A-drink-sodden-law-wants.html> .

DAILY MAIL (2005) 'Ministers "should rethink 24-hour drinking law"', Daily Mail, 13 January 2005, <http://www.dailymail.co.uk/news/article-334039/Ministers-rethink-24-hour-drinking-law.html> .

DAILY MAIL (2005) 'Blunkett voiced concerns over 24-hour drinking', Daily Mail, 16 January 2005, <http://www.dailymail.co.uk/news/article-334275/Blunkett-voiced-concerns-24-hour-drinking.html> .

DAILY MAIL (2005) '24-hour drinking reform in chaos', Daily Mail, 17 January 2005, <http://www.dailymail.co.uk/news/article-334356/24-hour-drinking-reform-chaos.html> .

DEPARTMENT OF CULTURE, MEDIA AND SPORT (2008) 'Evaluation of the Impact of the Licensing Act 2003', <http://www.culture.gov.uk/images/publications/Licensingevaluation.pdf> .

DORN, Nicholas (1983) Alcohol, Youth and the State. London: Croon Helm.

DURKHEIM, Emile (1970) Suicide. London: Routledge.

ENGELS, Friedrich (1993) The Condition of the Working Class in England . Oxford: Oxford University Press. 
ENGLISH CHARTIST CIRCULAR (1841-1844) 'Temperance Record', English Chartist Circular, Vols. 1-2, New York: Augustus M. Kelley.

ERIKSEN, Sidsel (1989) 'Drunken Danes and Sober Swedes? Religious revivalism and the temperance movements as keys to Danish and Swedish folk cultures', in Strath, Bo (ed.), Language and the Construction of Class Identities, Gothenburg: Gothenburg University Press.

EXPLANATORY NOTES (2003) 'Licensing Act 2003 - Explanatory Notes', <http://www.opsi.gov.uk/acts/acts2003/en/ukpgaen_20030017_en_1> .

FARRAR, F.W. (1893) 'Drink and Crime’, Fortnightly Review, Vol. 3, January-June 1893, pp. 783-796.

GREENAWAY, John (2003) Drink and British Politics since 1830. Basingstoke: Palgrave.

GUSFIELD, Joseph R. (1962) 'Status Conflicts and the Changing Ideologies of the American Temperance Movement', in David J. Pittman and Charles R. Snyder (editors) Society, Culture and Drinking Patterns . New York: John Wiley and Sons.

HARRISON, Brian (1971) Drink and the Victorians. London: Faber and Faber.

HOME OFFICE (1996) 'Home Office Circular',

<http://www.crimereduction.homeoffice.gov.uk/toolkits/ar020106.htm> .

HOMO (1830) 'Abuse of Spirituous Liquor', letter to the editor, The Times, 4 January 1830.

HUCKLE, Taisia, PLEDGER, Megan, and CASSWELL, Sally (2006) 'Trends in Alcohol-Related Harms and Offences in a Liberalized Alcohol Environment', Addiction, Vol. 101, pp. 232-242.

HUNT, Alan (1999) Governing Morals: a Social History of Moral Regulation , Cambridge: Cambridge University Press.

HUNT, W. (1841) History of Teetotalism in Devonshire. UK: Western Temperance Advocate Office.

JENKINS, Phillip (2009) 'Failure to Launch: Why do some issues fail to detonate social panics?', British Journal of Criminology, Vol. 49, pp. 35-47.

KAVANAGH, Trevor (2005) 'Cops' late drink warning', The Sun, 10 August 2005, <http://www.thesun.co.uk/sol/homepage/news/article110843.ece>.

KERSHAW, Chris, NICHOLAS, Sian, and WALKER, Alison (2008) 'Crime in England and Wales 2007/ 08', Home Office Statistical Bulletin, <http://www.homeoffice.gov.uk/rds/pdfs08/hosb0708. pdf> .

KNEALE, James (2001) 'The Place of Drink: temperance and the public, 1856-1914', Social and Cultural Geography, Vol. 2 (1), pp. 43-59.

LEA, Michael (2005) 'Pints failure at booze ban', The Sun, 31 October 2005, <http://www.thesun.co.uk/sol/homepage/news/article190781.ece> .

LEVINE, Harry G. (1993) 'Temperance Cultures: concern about alcohol problems in Nordic and Englishspeaking cultures', <http://soc.qc.cuny.edu/Staff/levine/temp-cult.htm> .

NEW YORK TIMES (1915) 'England may stop sale of all liquor', New York Times, 30 March 1915, <http://query.nytimes.com/mem/archive-free/pdf?res=9400E2DC123FE233A25753C3A9659C946496D6CF>

NORSTROM, Thor, and SKOG, Ole-Jorgen (2005) 'Saturday Opening of Alcohol Retail Shops in Sweden: an experiment in two phases', Addiction, Vol. 100, pp. 767-776.

PASCOE-WATSON, George (2008) '24hr booze Crackdown', The Sun, 4 March 2008, <http://www.thesun.co.uk/sol/homepage/news/justice/article872177.ece> .

PERRIE, Robin (2005) 'Revellers "field hospital”', The Sun, 23 November 2005, <http://www.thesun.co.uk/sol/homepage/news/article191835.ece> .

PLANT, Martin, and PLANT, Moira (2006) Binge Britain. Oxford: Oxford University Press.

PURVIS, Trevor, and HUNT, Alan (1993) 'Discourse, ideology, discourse, ideology, discourse, ideology...', British Journal of Sociology, Vol. 44 (3), pp. 473-498. 
ROBERTS, Bob (2008) 'Gordon Brown exclusive: any shop caught twice selling alcohol to U18s should lose its licence', Daily Mirror, 3 March 2008, <http://www.mirror.co.uk/news/topstories/2008/03/03/gordonbrown-exclusive-any-shop-twice-caught-selling-alcohol-to-u18s-should-lose-its-licence-89520-20338645/> .

ROWBOTHAM, Judith, and Stevenson. Kim (2003) Behaving Badly. Aldershot: Ashgate.

RUONAVAARA, Hannu (1997) 'Moral Regulation: a Reformulation', Sociological Theory, Vol. 15 (3), pp. 277-292.

SHIMAN, Lilian Lewis (1988) Crusade Against Drink in Victorian England. Basingstoke: Macmillan.

SUMNER, Maggie, and PARKER, Howard (1995) Low in alcohol: a review of international research into alcohol's role in crime causation. Portman Group.

THE SUN (2004) '24-hour pub cop fury', The Sun, 8 July 2004,

<http://www.thesun.co.uk/sol/homepage/news/article91326.ece> .

THE SUN (2005) 'Time will tell', The Sun, 22 January 2005,

<http://www.thesun.co.uk/sol/homepage/news/sun_says/article113699.ece> .

THE TIMES (1895) 'The National Temperance Congress', The Times, 5 October 1895.

THOMPSON, E.P. (1980) The Making of the English Working Class . Middlesex: Penguin.

TOWNSEND, Mark, and HINSCLIFF, Gaby (2005) 'New drink laws spark rape fears', The Observer, 27 November 2005.

TRAVIS, Alan, MUIR, Hugh, and CROWN, Rosie (2005) 'Government admits new drinking hours could lead to increase in offences', The Guardian, 23 November 2005.

WARNER, Jessica (2003) Craze: Gin and Debauchery in an Age of Reason . London: Profile Books.

WEBER, Max (1965) The Protestant Ethic and the Spirit of Capitalism . London: Unwin University Books.

WORLD HEALTH ORGANISATION (2004) 'WHO Global Status Report',

<http://www.who.int/substance_abuse/publications/global_status_report_2004_overview.pdf > .

WILLIAMS, Roger (2005) 'Sober lessons about drink', Observer, 27 November 2005,

<http://www.guardian.co.uk/uk/2005/nov/27/drugsandalcohol.football> .

WOODING, David (2005) 'Medics fear 24-hour pubs', The Sun, 3 January 2005,

<http://www.thesun.co.uk/sol/homepage/news/article100575.ece> . 